\title{
Deradicalization of Terrorism Prisoner: Evaluation of the Terrorism Client Guidance Program at the Surakarta Correctional Facility
}

\author{
Samto Hadi Isnanto \\ Universitas Negeri Jakarta \\ Email: samtoisnanto@gmail.com \\ Ma'ruf Akbar \\ Universitas Negeri Jakarta \\ Email: maruf.akbar@unj.ac.id \\ Billy Tunas \\ Universitas Negeri Jakarta \\ Email: tunas.billy@gmail.com
}

\begin{abstract}
The radicalism that leads to terrorism is a threat to almost every country in the world, leading many countries to employ a deradicalization program to deradicalize people that have been influenced by terrorist ideology. This research purpose is to evaluate the effectiveness of deradicalization effort conducted through "terrorism client guidance program at Surakarta Correctional Facility". Using the CIPP model of evaluation, data is collected from eighteen terrorism clients and a few structural officials as well as all related documents at Surakarta Correctional Facility. The result of this study found that: (1) Evaluation of context component is worth average, (2) Evaluation of input component is worth poor, (3) Evaluation of process component is worth good, and (4) Evaluation of product component is worth average. Overall, the effectiveness of deradicalization conducted through guidance for terrorism client program at Surakarta Correctional Facility is worth average. Although the total evaluation merit of the terrorist client's guidance program is still in the level of average, however, the author suggests that the program should be continued by revising some areas of concern.
\end{abstract}

Keywords: Deradicalization, Evaluation Program, Guidance of Terrorism Client.

Received: 23 September 2020 ;

Accepted: 29 September 2020 ;

Publish; December 2020.

\section{How to Cite:}

Hadi, S., Akbar, M., Tunas, B. (2020).

Deradicalization of Terrorism Prisoner: Evaluation of the Terrorism Client Guidance Program at the Surakarta Correctional Facility. International Journal of Human Capital Management, 4 (2), 96-113. https://doi.org/10.21009/IJHCM.04.02.09 


\section{INTRODUCTION}

Terrorism is a threat to human security at the global, regional and national level, leading many countries to employ a deradicalization program as a soft strategy to complement the repressive strategy to fight against terrorism (Amanda. K, 2009; Boucek, 2008; Rabasa et al., 2011). Deradicalization is a concept that has been developed and implemented in various countries. In Yemen, Saudi Arabia, Egypt, Singapore, Philippine, and Indonesia. Different country offers different strategy and tactic in implementing deradicalization program. Economic, political, and social context in the country becomes the main consideration to develop the program. Saudi Arabia and Singapore use comprehensive approach by synergizing multi agency to carry out the work. Yemen uses prominent Ulema to deradicalize the target, while Indonesia uses ex terrorist and encouraging multi agency to participate on deradicalization program.

Indonesia started to formalize deradicalization strategy since the inception of presidential decree number 15/2003. Deradicalization of terrorists is considered as national counter-terrorism program through a soft approach. There are two strategies in the deradicaliazation program, which are deradicalization in the prison and deradicalization outside the prison (Hamka, 2013). Correctional Institution has the duty and responsibility to carry out deradicalization through coaching and fostering terrorism convicts in prisons. Meanwhile, the Correctional Facility has the duty and responsibility to carry out deradicalization through the guidance of terrorism clients outside prisons (Indonesian Act. No. 15/1995). The role of Correctional Facility is very much important, not only in preparing for integrating terrorist clients to the community and preparing them to have the knowledge and skill for their live after release but also to moderate their radical ideology.

Terrorist client, in some degree, is a person with a special condition. He is a prisoner in probation. His status is still a prisoner but is living outside the prison and socializing with the public community. They face several problems after their release. For instance: lack of skill to generate income to provide for their life; negative stigma from the community; difficulties to access economic sources, influence from their old radical web, and many other problems of life. This is the problem that Community Advisors at Surakarta Correctional Facility should deal with. Therefore the activity of mentoring and counseling terrorism clients requires specific knowledge and skills related to basic needs, as well as certain approaches that can be accepted by the terrorism client. The results of the researchers' preliminary observations in August 2014 at Surakarta Correctional Facility, found interesting findings. These findings include the very limited capacity of Community Advisors/Client's Councelor, and infrastructure owned by Surakarta Correctional Facility in dealing with terrorism clients. This limitation is followed by technical problems, such as unclear client addresses, difficult topography to address clients, and uncooperative clients.

Apart from the previous complications, clients of terrorism face difficult social conditions after they are free from correctional institutions. In fact, according to some clients of terrorism, life outside the prison is more difficult than life inside prison (JT, Interview. 12 December 2014). This is due to difficulties in adapting, opening work networks, finding or creating jobs, capital constraints, and so on. This obstacle is increasingly difficult to overcome in an apathetic society and tends to attach a negative stigma to clients of terrorism (TA, Interview, October 25, 2014). Meanwhile, the Government has not given an adequate attention to optimizing the terrorism client guidance program, making guidance even more difficult.

Author also notices that there are many articles mentioning and discussing about deradicalization program (Mintardja, n.d.), (Johnson, n.d.), (Schmid, 2013), (John \& Braddock, 2010), (Istiqomah, n.d.), (Suratman, 2018), (W.Kruglanski et al., 2014), however none of them assesses the effectiveness of deradicalization program conducted by the Correctional Facility. In addition, Surakarta Correctional Facility which is responsible for guiding terrorism clients after they are released from prison, experiences various limitations such as human resources, budget constraints, facilities, and infrastructure, so that the effectiveness of the guidance of terrorism 
clients at Surakarta Correctional Facility is questionable. Therefore, the researcher is interested in evaluating how effective the terrorism client guidance program at Surakarta Correctional Facility is.

There are several reasons why the terrorist client guidance program at Surakarta Correctional Facility is selected as case study by the author. The reasons are namely: (1) Surakarta Correctional Facility accommodate the highest number of terrorist clients at the time of research, (2) Surakarta is the center of gravity of the radical terrorist movement, and (3) Data access is not very difficult. The Surakarta correctional center as the apparatus who are responsible for guiding terrorism clients after they leave Prisons experience various limitations, such as: human resources, budget, facilities and infrastructure so that the guidance of terrorism clients at the Surakarta Correctional Center has not matched expectations or its effectiveness is questioned. Therefore, the researcher is interested in evaluating how effective is the terrorism client mentoring program at Surakarta Correctional Center.

\section{LITERATURE REVIEW}

\section{Concept of Deradicalization}

According to Ashour, deradicalization is a process of transforming the radical ideology of Islamist groups towards moderation and also abandoning violence as legitimacy in achieving its goals. He stated that "de-radicalization is a process of relative change within Islamist movements, one in which radical group reverses its ideology and de-legitimizes the use of violent methods to achieve political goals, while also moving towards and acceptance of gradual social, political and economic changes within a pluralist's context" (Ashour, 2009:6). Meanwhile, Golose explained that deradicalization is a process to restore and/or neutralize radicalism through an interdisciplinary approach back to mainstream ideology. The various interdisciplinary approaches can include sociological, legal, economic, socio-cultural, and psychological approaches. With these efforts, it is believed that those who have been influenced by violent radicalism can leave this understanding and not take violent actions to achieve their goals (Golose, 2009:174-175). However, Horgan in Rabassa (2011) stated that it is almost impossible to reverse a terrorist radical ideology, the only impact of deradicalization program is just to disengage them from their radical terrorist group and violent behavior to pursue their goals (Rabassa, 2011). Meanwhile, Presidential Decree No. 46 of 2010 defines deradicalization as:

All efforts to transform radical beliefs or ideologies to become non-radical with multi- and interdisciplinary approaches through identification, rehabilitation, re-education, and resocialization programs for suspects, prisoners, ex-convicts and their families and networks that are indicated as radical by promoting the principles of empowerment, human rights, supremacy law, and equality.

\section{Concept of Effectiveness}

Bartol and Martin define effectiveness as the ability to choose a goal and succeed in realizing it. Effectiveness refers to a predetermined goal with tangible results or a predetermined target with a resulting target. If the comparison is considered equal then it is said to be effective (Bartol \& Martin, 1991). According to Tampubolon, effectiveness in an organizational context is the level of achievement of previously agreed goals or objectives. Activities, programs, or organizations are said to be effective if these predetermined goals can be achieved. Furthermore, it is explained that organizational effectiveness consists of a combination of individual effectiveness and group effectiveness. Even so, the effectiveness of an organization is not just the sum of the two components, but it is even greater because of the synergy factor within the organization that increases the level of effectiveness (Tampubolon, 2012:175). 


\section{Concept of Evaluation Program}

Evaluation of a policy, program or activity is part of the management cycle in an organization. According to Arikunto, evaluation is defined as an activity to find, determine an amount or value. From this, it can be elaborated that evaluation is an activity that must be well prepared by the evaluator to find and determine an appropriate and accurate value scale. Accuracy is very important because the result of an evaluation is used by the management in making a decision. In relation to programs or activities, the decision is usually in the form of terminating the program, if the results of the evaluation show that the program does not have a positive or good value (Arikunto \& Jabar, 2014:1). In line with this view expressed by Grounloud in Jali and Mulyono stated that evaluation is a systematic process to determine or decide to what extent the objectives of a program can be achieved (Djaali \& Mulyono, 2004:1). Meanwhile, according to Wirawan, evaluation or evaluation research is a research activity to collect, analyze, and present useful information on the object being evaluated by comparing it against standards or evaluation benchmarks whose results are used for decision making on whether the object being evaluated is continued or stopped (Wirawan, 2011:7). Evaluation is also mentioned as a process of applying scientific procedures in collecting correct information to make decisions about educational programs (Purwanto\& Atwi, 1999:9).

\section{Concept of Terrorism Client Guidance Program}

Jones stated that guidance is the assistance given to individuals to develop their potential so that they can make choices and capacity building in determining their life (Jones, 1934). In broad definition, guidance is the assistance given to individuals in making intelligent choices adjusting their lives. The ability to make choices is not innate; it must be developed. The fundamental purpose of the guidance is to develop each individual, up to the limit of their capacity, the ability to solve their problem and to make adjustments to it.

The type of guidance provided to correctional clients must be tailored to the problems and needs of the correctional client. The form of guidance to clients can be given specifically or a combination of several types of guidance tailored to client needs. Broadly speaking, the type of guidance at the Correctional Facility is personality and independence guidance. In more detail, in accordance with Article 3 of Government Regulation No.31 of 1999 concerning Guidance and Guidance of Correctional Assisted Citizens, the types of guidance provided to assist citizens, such as guidance of devotion to God Almighty; Guidance on awareness of the nation and state; Intellectual guidance; Attitude and behavior guidance; Physical and spiritual health guidance; Legal awareness guidance; Healthy reintegration guidance with communities; Work skills guidance; and work training and production guidance.

\section{CIPP Program Evaluation Model}

The context, input, process, product or CIPP evaluation model is a well-known evaluation model and widely used in evaluating a program or activity. Stufflebeam in Wirawan (2011) states that evaluation is a delineating process, obtaining and providing useful information to assess decision-making alternatives (Wirawan, 2011: 328). This model can evaluate a program or project holistically and comprehensively because it is a combination of formative and summative evaluation. Furthermore, he explains that the components of this evaluation as follow:

1. Evaluation context. It analyzes and evaluate the context of the evaluation object. For example, why a program is needed, it is necessary to examine the background of the program. Furthermore, the merit of the program like vision, mission, goals and objectives 
of the program is drawn up. This is where we see the suitability of the vision, mission, goals and objectives with the needs of the program.

2. Input evaluation. This evaluation is a continuation of the previous evaluation. It evaluates things in relation to the strategy, planning and activities of the program to achieve the vision, mission and objectives that have been prepared in context of the previous evaluation.

3. Process evaluation. In this evaluation, the implementation of the program is at the core of what should be evaluated as a continuation of the input evaluation.

4. Evaluation of products or results. Evaluation in this component focuses on what has been produced from the program, even to what impact it has.

In this research, the researcher chose the CIPP evaluation model as an evaluation tool in measuring the effectiveness of the terrorism client guidance program at Surakarta Correctional Facility. The reason for using this model is the need to carry out a holistic evaluation of the program the context to the product of the program.

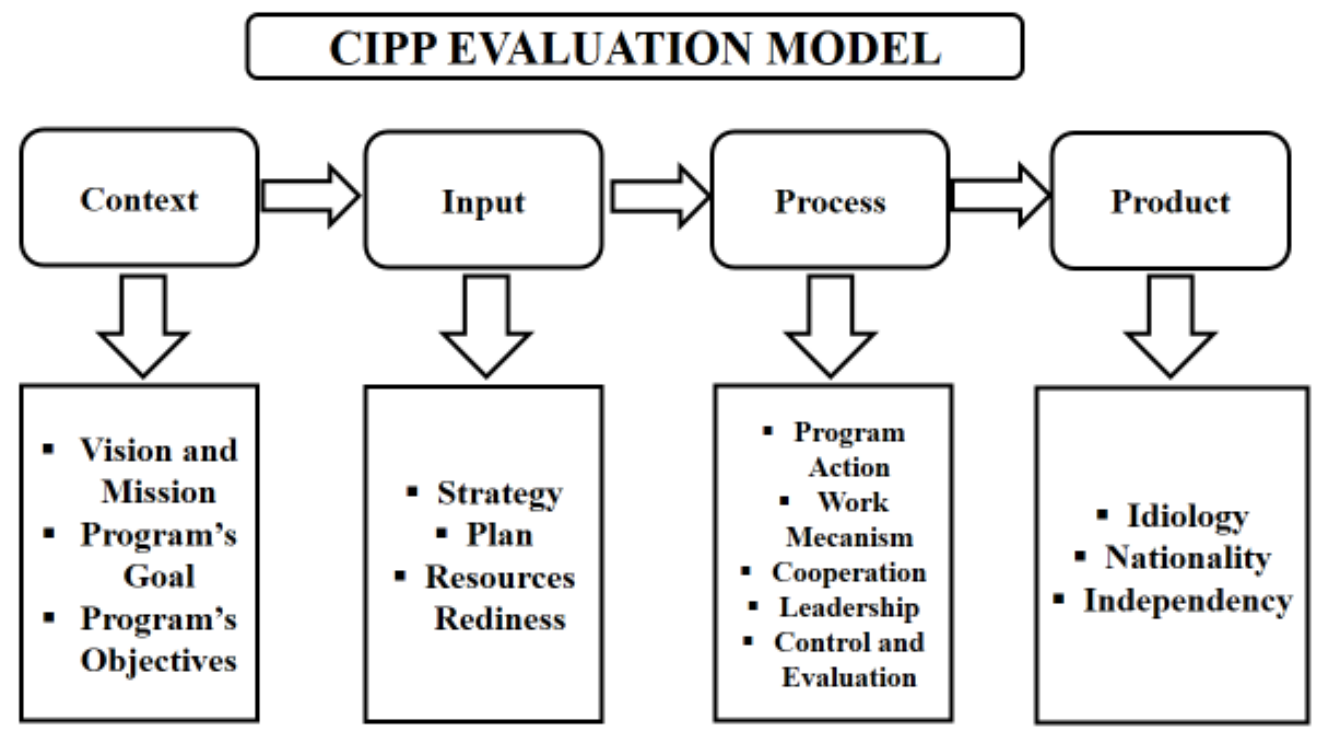

Picture 1. CIPP Evaluation Model (Stufflebeaml \& Shrinkfield, 1987)

\section{RESEARCH METHOD}

\section{Goal, Approach, and Method}

The aim of this research is to evaluate the terrorism client guidance program at Surakarta Correctional Facility in 2009-2015. The approach of this research is qualitative evaluation using the Context, Input, Process, Product (CIPP) evaluation model developed by Daniel Stufflebeam (Aziz et al., 2018). The qualitative approach seeks to reveal the various uniqueness that exists in individuals, groups, communities, or organizations in everyday life in a comprehensive, detailed, and deep manner, and can be scientifically accounted for (Ghony \& Fauzan Almanshur, 2012:32). By using CIPP method of evaluation, the evaluation consists of comprehensive dimensions, which includes context, input, process and product.

\section{The Data}


Primary and secondary data collected through interviews, questionnaires, field observation and document studies. All the data were analyzed by reducing, grouping, interpreting, presenting and then summarizing them to determine the results. Data validation was carried out using triangulation, both in the form of content and data sources. Conclusions are made after the data from the field research results are compared with the evaluation criterion previously made by the researcher.

\section{Design}

The design of the research based on Stufflebeam CIPP model of evaluation. Starting from the identification of each element of the four components context, input, process, and product, then researcher develop evaluation criteria for each component of evaluation. After gathering data from the field finish, data belong to each component compared with the evaluation criteria to decide the merit or worth of each evaluation component. The final step is the recommendation whether the program should be stopped, continued with some revision or spread away to other area to be implemented. The design model see illustration below.

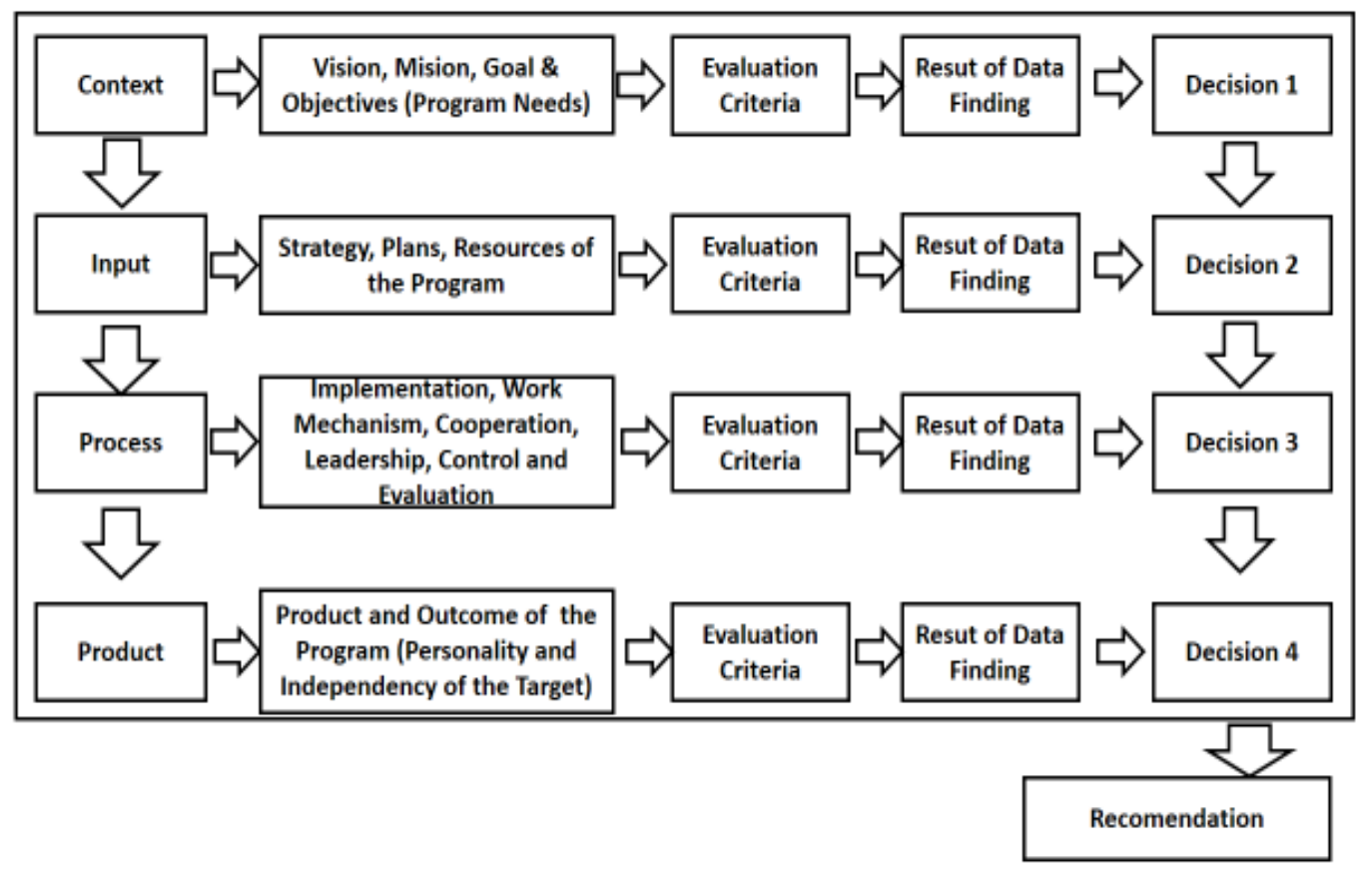

Picture 2. Research Design

Source: Author adoption from Stufflebeam model

\section{Research Question}

Based on the aim and the background of the research, there are four question that the researcher seek to answer, they are the merit or worth of the evaluation of the context, input, process, and product of the component of evaluation.

\section{The Metric}

To assess the effectiveness of the terrorism client guidance program at Surakarta Correctional Facility, reseacher developed a matric to define the level of merit or worth for each component and all of its aspect being evaluated. The metric is shown on the table below. 
Table 1. Assessment of Merit or Worth Based on Compliance with Evaluation Criteria

\begin{tabular}{|c|c|c|}
\hline Scale & Rating & Assessment \\
\hline 1 & Poor & $\begin{array}{r}\text { When no to only a few of evidence or data finding meet to } \\
\text { the evaluation criteria }\end{array}$ \\
\hline 2 & Average & $\begin{array}{c}\text { When a few to several of evidence or data finding meet to } \\
\text { the evaluation criteria }\end{array}$ \\
\hline 3 & Good & $\begin{array}{c}\text { When several to lots of evidence or data finding meet to the } \\
\text { evaluation criteria }\end{array}$ \\
\hline 4 & Excelent & $\begin{array}{c}\text { When lots of to plenty of evidence or data finding meet to } \\
\text { the evaluation criteria }\end{array}$ \\
\hline
\end{tabular}

\section{RESULT AND DISCUSSION}

\section{The Effectiveness of the Terrorism Client's Guidance Program at Surakarta Correctional Facility}

To assess the effectiveness of the terrorism client guidance program at Surakarta Correctional Facility, the CIPP evaluation model was used. Therefore, the components that are assessed are the components of context, input, process, and products or results. The data obtained from the field were compared with the evaluation criteria to judge the merit of the program. The merit of each component depends on how the evidence from the field is compared to the criteria of evaluation. The more the evidence meet the criteria the better the merit of the aspect of evaluation is.

\section{Context Component Evaluation}

There are three aspects of context component evaluated, which are the formulation of vision and mission, goal, and objectives. During an interview with a client's councelor (M, Interview, 15 December 2014), he said that his party had never formulated the objectives of terrorism client guidance based on the needs analysis. What is expressed in that vision, mission, goal, and objective are the aim of the Surakarta Correctional Facility Headquarters in carrying out its task of correctional guiding for the whole client in general, including clients of terrorism. This means that the vision, mission, goal, and objective of the terrorism client guidance program has not been formulated based on the specific needs for terrorism clients but is based on the needs for guidance from all correctional clients who are under the auspices of the Surakarta Correctional Facility. According to John P. Kotter, vision, mission, and goal are important elements for guiding the whole organization to achieve good performance. For instance, vision must be well known and understood to people within the organization, even stakeholders (Kotter \& Schlesinger, 2008)

For more details, the following are the results of the terrorism client's guidance program evaluation from each individual aspects.

a. Vision and mission aspect. Formulation for the vision and mission, objectives and target for the terrorism client guidance program is not yet based on the analysis for the needs of terrorism client's guidance program, but is only a part of the general society guidance program. This results in the special needs of terrorism clients being unfulfilled and in turn makes the results not optimal.

b. Aspect of the program's objective. Objective is not formulated based on the analysis of the needs of terrorism client's guidance program but based on objective statement stated on the Organization Operational Procedure of Surakarta Correctional Facility. However, the needs of 
terrorism clients are still accomodated well. The objectives are also formulated according to the legal aspects in relation.

c. Program target aspect. There is a written formulation for the target. However it is not specific, measured, realistic, dan there is a clear time limit on the terrorism client's guidance program.

Table 2. Context Component Evaluation Report

\begin{tabular}{|c|c|c|c|}
\hline Aspects Evaluated & Evaluation Criteria & Research Findings & Score \\
\hline & $\begin{array}{l}\text { 1.1. The program's } \\
\text { vision and mission is } \\
\text { formulated according } \\
\text { to analysis of the } \\
\text { terrorism client } \\
\text { guidance program's } \\
\text { needs. }\end{array}$ & $\begin{array}{l}\text { There is vision and mission, however } \\
\text { it is formulated according to the } \\
\text { correctional guidance program in } \\
\text { general. } \\
\text { The program's vision and mission is } \\
\text { not formulated according to the } \\
\text { analysis of the terrorism client's } \\
\text { guidance needs. }\end{array}$ & Average \\
\hline $\begin{array}{l}\text { 1. Formulation of } \\
\text { the program's } \\
\text { vision and } \\
\text { Mission }\end{array}$ & $\begin{array}{l}\text { 1.2. The vision and } \\
\text { mission is socialized } \\
\text { and understood by all } \\
\text { the stakeholders. }\end{array}$ & $\begin{array}{l}\text { Socialization is still limited to the } \\
\text { internal environment of the Surakarta } \\
\text { correctional facility. Stakeholders, } \\
\text { guidance target and terrorism client is } \\
\text { uninformed on the vision and mission } \\
\text { of the program. }\end{array}$ & Average \\
\hline & $\begin{array}{l}\text { 2.1. There is a goal } \\
\text { formulation based on } \\
\text { the terrorism client } \\
\text { guidance program's } \\
\text { needs. }\end{array}$ & $\begin{array}{l}\text { Goal formulation can be found, } \\
\text { however it is not formulated } \\
\text { according to the analysis of the needs } \\
\text { of terrorism client's guidance } \\
\text { program. The goal is formulated } \\
\text { according to the analysis of the needs } \\
\text { of the general client's guidance } \\
\text { program. }\end{array}$ & Average \\
\hline $\begin{array}{l}\text { 2. Formulation of } \\
\text { the program's } \\
\text { goals }\end{array}$ & $\begin{array}{l}\text { 2.2. Goal formulation is } \\
\text { based on legal aspect. }\end{array}$ & $\begin{array}{l}\text { Goal is formulated based on Indonesia } \\
\text { Act No. } 15 / 1995 \text { and Organizational } \\
\text { Operation Procedure of Surakarta } \\
\text { Correctional Facility }\end{array}$ & Good \\
\hline $\begin{array}{l}\text { 3. Program } \\
\text { Objective }\end{array}$ & $\begin{array}{l}\text { A SMART written } \\
\text { formulation on the } \\
\text { program's objective to } \\
\text { achieve is stated. }\end{array}$ & $\begin{array}{l}\text { A written formulation of the } \\
\text { program's objective is stated but does } \\
\text { not show SMART. } \\
\text { The program's goal containing } \\
\text { objectives to achieve in terorrism } \\
\text { client guidance is also not described in } \\
\text { detail. }\end{array}$ & Average \\
\hline
\end{tabular}

Based on the table above, it can be explained that the results of the evaluation of the context component is average. This means that only a few to several evidence meets the criteria of evaluation. There are several causes why the worth of context component is unable to reach the level of excellent or even good. The most problematic in this case is because that there is no target 
assessment for the client's needs in developing vision, mission, goal, and objectives of the program. In addition, the program's objective formulas does not meet the SMART principle which are specific, measurable, achievable, relevant, and time bound limited (Marsh, 1978).

\section{Input Evaluation Component}

In terms of preparing human resources, Surakarta Correctional Facility has not reached the optimal standard, both in quantity and quality. The number of client's counselor for adult clients is only 15 people, while the clients that must be served are up to 800 people. Each official member must handle more than 50 correctional clients, which is a very large number. Meanwhile, from the quality aspect, there is a client's Counselor members with only a high school level certificate and does not have specific knowledge and skills to guide terrorism clients yet.

Of the 15 client's Counselor for adult clients, eight people handled terrorism clients. Those eight people are also still serving guidance for clients other than terrorist convicts. Out of the eight client's Counselor who handled terrorism clients, only two of them had attended special technical guidance seminars for terrorism clients. Client's Counselor ability to provide guidance to terrorism clients is not sufficient, so it needs to be improved through training and/or seminars on terrorism. This is reported by Counselor, (K, Interview, 3 January 2015) as in the following passage:

The ability of Community Guidance personnel still needs to be improved, especially in the case of special training or technical guidance on mentoring terrorism-specific clients. The number of Counselor in the Correctional Facility is quite good, although it needs additional people. However the quality of them still has to be improved so that the guidance provided is in accordance with the needs and conditions of the client. It is necessary to increase or improve the training for Counselor, especially those dealing with terrorist clients, most of them still a lack of knowledge about terrorism clients.

A similar feeling was also reported by the Head of Section for Client's Guidance, Surakarta Correctional Facility (HP, Interview, 5 January 2015).

Most of the Client's Counselor at Surakarta Correctional Facility already have knowledge about client mentoring in general, but only a few people have attended seminars or technical guidance on handling terrorism problems.

For more details, the following are the results of terrorism client's guidance program evaluation from each individual aspects.

a. Program strategy aspect. The evaluation result is average because only a few evaluation criteria are meet. The formulation of the strategy is not focused on the objective of terrorism client guidance.

b. Program plan aspect. The evaluation result in this aspect is average. A guidance for behaviour and autonomy plan is available and scheduled, however both of those activities are not specifically for terrorism clients and are incidental, especially in the guidance program for terrorism clients.

c. Organization preparedness. The result of this aspect evaluation is good. Most of the required criteria are fulfilled. The only minus is that there is no special unit dedicated to handle terrorism clients.

d. Human resourcess preparedness is good. Most of the criterias are fulfilled. The minus here is that there is shortage on the number of councelors competent in providing guidance for terrorism clients.

e. Facility preparedness aspect. The result for this is poor. There is a lot of unfulfilled criterias. For example there is no room exclusively for consultation, no room 
specifically for autonomy guidance, and transportation \& comunication support for councelor is not provided.

f. Budget preparedness aspect. The result for this is poor. Only a few criterias are fulfilled.

g. Guidance subject preparation aspect. The result for this aspect is average. This is due to an unrelevant guidance subject, the subject does not answer to the needs of the clients, and module or other written documents for the subject is not provided.

For more detail report regarding the merit of the input component of evaluation see the following table below.

Table 3. Input Component Evaluation Report

\begin{tabular}{|c|c|c|c|}
\hline Aspects Evaluated & Evaluation Criteria & Research Findings & Score \\
\hline \multirow[t]{2}{*}{$\begin{array}{ll}1 . & \text { Program } \\
& \text { Strategy } \\
& \text { Formulation }\end{array}$} & $\begin{array}{l}\text { 1.1 Terrorism client } \\
\text { guidance program } \\
\text { strategy formulation } \\
\text { can be found. }\end{array}$ & $\begin{array}{l}\text { Strategy formulation is found in the } \\
\text { annual work plan but was only part } \\
\text { of a general public client guidance } \\
\text { strategy. }\end{array}$ & Average \\
\hline & $\begin{array}{l}1.2 \text { Strategy is } \\
\text { formulated as clear as } \\
\text { possible for the } \\
\text { purpose of terrorism } \\
\text { client guidance. }\end{array}$ & $\begin{array}{l}\text { Strategy has not been formulated } \\
\text { clearly towards the goal of } \\
\text { guidance for terrorism clients. }\end{array}$ & Poor \\
\hline Aspects Evaluated & Evaluation Criteria & Research Findings & Score \\
\hline \multirow[b]{2}{*}{ 2. Program Plan } & $\begin{array}{l}\text { 2.1. Plan for } \\
\text { behavioural guidance } \\
\text { program according to } \\
\text { analysis on the needs } \\
\text { of terrorism client can } \\
\text { be found. }\end{array}$ & $\begin{array}{l}\text { Schedule for behavioural guidance } \\
\text { such as counseling in the form of } \\
\text { discussions for topics related to } \\
\text { religion, nationality and health, can } \\
\text { be found. However these schedules } \\
\text { are incidental during counseling. } \\
\text { There is no terrorism client } \\
\text { behavioural guidance schedule } \\
\text { specifically formulated. }\end{array}$ & Average \\
\hline & $\begin{array}{l}\text { 2.2. Plan for } \\
\text { autonomy guidance } \\
\text { program according to } \\
\text { the analysis for } \\
\text { terrorism client's } \\
\text { needs can be found. }\end{array}$ & $\begin{array}{l}\text { Schedule for skill training and } \\
\text { provision to prepare the guidanced } \\
\text { citizens in working after they are } \\
\text { fully released can be found. } \\
\text { However the program schedule is } \\
\text { incidental, and not routinely } \\
\text { scheduled. There is no specific } \\
\text { autonomy guidance program } \\
\text { schedule for terrorism clients. }\end{array}$ & Average \\
\hline \multirow[t]{2}{*}{ Aspects Evaluated } & Evaluation Criteria & Research Findings & Score \\
\hline & $\begin{array}{l}\text { 3.1. An Organization } \\
\text { structure can be } \\
\text { found. }\end{array}$ & $\begin{array}{l}\text { Through researching documents, an } \\
\text { organization structure for the } \\
\text { correctional facility can be found in } \\
\text { the strategic plan and in the program }\end{array}$ & Good \\
\hline
\end{tabular}




\begin{tabular}{|c|c|c|c|}
\hline \multirow{4}{*}{$\begin{array}{ll}\text { 3. } & \text { Organizational } \\
& \text { Structure }\end{array}$} & & $\begin{array}{l}\text { plan for correctional client } \\
\text { guidance. }\end{array}$ & \\
\hline & $\begin{array}{l}\text { 3.2. There is a specific } \\
\text { division for terrorism } \\
\text { client guidance. }\end{array}$ & $\begin{array}{l}\text { A specific division for terrorism } \\
\text { client guidance program is not } \\
\text { found. }\end{array}$ & Poor \\
\hline & $\begin{array}{l}\text { 3.3. Organization is } \\
\text { lean in structure / } \\
\text { simple. }\end{array}$ & $\begin{array}{l}\text { Surakarta correctional facility } \\
\text { organization is quite simple and } \\
\text { provides easy supervision and } \\
\text { control of the officers. }\end{array}$ & Good \\
\hline & $\begin{array}{l}\text { 3.4. Organization has a } \\
\text { list of job descriptions } \\
\text { for each officials. }\end{array}$ & $\begin{array}{l}\text { Job descriptions are found in the } \\
\text { strategic plan and also in the } \\
\text { comprehensive program plan, even } \\
\text { though a job description for the } \\
\text { terrorism client guidance officer is } \\
\text { not available yet. }\end{array}$ & Good \\
\hline Aspects Evaluated & Evaluation Criteria & Research Findings & Score \\
\hline \multirow{4}{*}{$\begin{array}{l}\text { 4. Human } \\
\text { Resources }\end{array}$} & $\begin{array}{l}\text { 4.1. The number of } \\
\text { counselor is adequate. }\end{array}$ & $\begin{array}{l}\text { One counselor provides guidance for } \\
2 \text { terrorism clients and a few other } \\
\text { adult clients. Ideally one councelor } \\
\text { handles one terrorism client so as to } \\
\text { provide more time for mentoring. }\end{array}$ & Average \\
\hline & $\begin{array}{l}\text { 4.2. Councelor has a } \\
\text { bachelor degree. }\end{array}$ & $\begin{array}{l}\text { Out of } 8 \text { councelors, seven of them } \\
\text { has a bachelor degree at minimum. }\end{array}$ & Good \\
\hline & $\begin{array}{l}\text { 4.3. Educational } \\
\text { training on counter } \\
\text { terrorism. }\end{array}$ & $\begin{array}{l}\text { Out of } 8 \text { councelors, only two has } \\
\text { received education on terrorism. }\end{array}$ & Poor \\
\hline & $\begin{array}{l}\text { 4.4. Motivation and } \\
\text { commitment for the } \\
\text { organization. }\end{array}$ & $\begin{array}{l}\text { The councelors demonstrated a } \\
\text { good motivation and commitment. }\end{array}$ & Good \\
\hline Aspects Evaluated & Evaluation Criteria & Research Findings & Score \\
\hline \multirow[b]{3}{*}{$\begin{array}{ll}\text { 5. Facility } \\
\text { Readiness }\end{array}$} & $\begin{array}{l}\text { 5.1. Transportation } \\
\text { support for the officers } \\
\text { is available. }\end{array}$ & $\begin{array}{l}\text { There is no transportation support } \\
\text { specifically for councelors. }\end{array}$ & Poor \\
\hline & $\begin{array}{l}\text { 5.2. Communicational } \\
\text { support for officer and } \\
\text { client comunication is } \\
\text { available. }\end{array}$ & $\begin{array}{l}\text { There is no comunication support } \\
\text { specifically for terrorism client } \\
\text { councelors. }\end{array}$ & Poor \\
\hline & $\begin{array}{l}\text { 5.3. Consultation room } \\
\text { specifically for client } \\
\text { consultation is } \\
\text { available. }\end{array}$ & $\begin{array}{l}\text { There is no room specifically for } \\
\text { terrorism client consultation } \\
\text { sessions. }\end{array}$ & Poor \\
\hline
\end{tabular}




\begin{tabular}{|c|c|c|c|}
\hline & $\begin{array}{l}\text { 5.4. Training hall for } \\
\text { clients is available. }\end{array}$ & $\begin{array}{l}\text { There is no training hall } \\
\text { specifically for terrorism clients. }\end{array}$ & Poor \\
\hline & $\begin{array}{l}\text { 5.5. Support on the } \\
\text { availability of office } \\
\text { stationaries is provided }\end{array}$ & $\begin{array}{l}\text { There is support on office } \\
\text { stationaries, however it is not } \\
\text { adequate enough. }\end{array}$ & Average \\
\hline Aspects Evaluated & Evaluation Criteria & Research Findings & Score \\
\hline $\begin{array}{ll}\text { 6. } & \text { Budget } \\
& \text { Readiness }\end{array}$ & $\begin{array}{l}\text { 6.1. Budget is stated in } \\
\text { the annual Budgetary } \\
\text { Program. }\end{array}$ & $\begin{array}{l}\text { Expense budget for terrorism } \\
\text { clients is not stated in the annual } \\
\text { Budgetary Program.. }\end{array}$ & Poor \\
\hline & 6.2. Specific budget & $\begin{array}{l}\text { Budget for convict guidance is not } \\
\text { specific. It is still combined with } \\
\text { budget for other clients. }\end{array}$ & Poor \\
\hline & 6.3. Adequate amount & $\begin{array}{l}\text { The budget amount is less than } \\
\text { adequate. It is less than Rp. } \\
100.000 \text { monthly. }\end{array}$ & Poor \\
\hline & 6.4. Transparent & $\begin{array}{l}\text { Budgeting plan is done } \\
\text { transparently. }\end{array}$ & Good \\
\hline Aspects Evaluated & Evaluation Criteria & Research Findings & Score \\
\hline \multirow{3}{*}{$\begin{array}{l}\text { 7. Material } \\
\text { Guidance }\end{array}$} & $\begin{array}{l}\text { 7.1. Terrorism client } \\
\text { guidance subject is } \\
\text { stated in the annual } \\
\text { program. }\end{array}$ & $\begin{array}{l}\text { Guidance subject is written in the } \\
\text { program as how it was planned out, } \\
\text { but is stated in general and not } \\
\text { specify for terrorism client. }\end{array}$ & Average \\
\hline & $\begin{array}{l}\text { 7.2. Guidance subject } \\
\text { is prepared in advance } \\
\text { in the form of a } \\
\text { document. }\end{array}$ & $\begin{array}{l}\text { Guidance subject was not prepared } \\
\text { in document. The councelor was not } \\
\text { handed out the papers containing } \\
\text { materials and details needed. }\end{array}$ & Poor \\
\hline & $\begin{array}{l}\text { 7.3. Guidance subject } \\
\text { is relevant with the } \\
\text { purpose of the } \\
\text { guidance. }\end{array}$ & $\begin{array}{l}\text { Only a few of the program's subject } \\
\text { was relevant to the needs of } \\
\text { terrorism clients. }\end{array}$ & Average \\
\hline
\end{tabular}

Based on the table above, it can be explained that the results of the evaluation of the input component is average. This means that only a few to several evidence that meet to the criteria of evaluation. Some of the aspects of element evaluated are poor. For example facilities and budget. This is quite a big problem for the Correctional Facility to run the program.

\section{Process Component Evaluation}


The main activity in the terrorism client guidance program at Surakarta Correctional Facility is personality guidance and independence guidance. Personality guidance is directed to make clients aware of their mistakes and subsequently not repeat their unlawful acts. Clients are also directed and facilitated to prepare for their reintegration to the community so that they can be immediately accepted by the community where the clients continue their lives after serving their sentence. In fact, the implementation of mentoring activities for terrorism clients still has many weaknesses. For example, one of the clients of terrorism said that he had not followed the guidance schedule several times and was able fill attendance list trough phone call or short message (M, Interview, November 2014). Similar statements were also made by other clients of terrorism (JT, November 2014 Interview).

For more details, the following are the results of terrorism client's guidance program evaluation from each individual aspects.

a. Implementation of behavioural and autonomy activity aspect. The result for this is in the catagory of good. In this sub-component, the weakness is in the consistency from the councelors with their clients and the inability of program executors in providing the guidance materials suitable for the needs of terrorism clients.

b. Work mechanism aspect. The result for this is good. Work procedure is available and implemented by correctional councelors. However, specific work procedure for terrorism clients is not available yet.

c. Cooperation aspect. The result for this is good. Internal and external cooperation is implemented well. The only improvement needed is the cooperation between the polica and attorney that still needs to be worked on.

d. Control and evaluation aspect. The result for this aspect is average. This is due to the permisive attitude from councelors to the clients absent from the guidance activities. Councelors are also unable to supervise terrorism clients who is already in the public community.

Tabel 4. Process Component Evaluation Report

\begin{tabular}{|c|c|c|c|}
\hline $\begin{array}{l}\text { Aspects } \\
\text { Evaluated }\end{array}$ & Evaluation Criteria & Research Findings & Score \\
\hline \multirow[b]{2}{*}{$\begin{array}{l}\text { 1. Guidance } \\
\text { Implementati } \\
\text { on }\end{array}$} & $\begin{array}{l}\text { 1.1. The scheduled once } \\
\text { a month counceling must } \\
\text { be fulfilled. Attendance } \\
\text { can be used to measure } \\
\text { obedience. }\end{array}$ & $\begin{array}{l}\text { Officers can sometimes be } \\
\text { permissive. Attendance can even } \\
\text { be done through a phone call } \\
\text { (online attendance). }\end{array}$ & Average \\
\hline & $\begin{array}{l}\text { 1.2. To understand the } \\
\text { client's activities in } \\
\text { public community, open } \\
\text { and closed method of } \\
\text { supervision can be done } \\
\text { by councelors. }\end{array}$ & $\begin{array}{l}\text { Closed supervision proves to be } \\
\text { difficult to do due to the limited } \\
\text { resources and geographical } \\
\text { obstacles. While open supervision } \\
\text { is done through attendance. }\end{array}$ & Average \\
\hline $\begin{array}{l}\text { Aspects } \\
\text { Evaluated }\end{array}$ & Evaluation Criteria & Research Findings & Score \\
\hline \multirow{2}{*}{$\begin{array}{l}\text { 2. Work } \\
\text { Mechanism }\end{array}$} & $\begin{array}{l}\text { 2.1. There is a specific } \\
\text { work procedure for the } \\
\text { guidance of terrorism } \\
\text { clients. }\end{array}$ & $\begin{array}{l}\text { There is no specific work } \\
\text { procedure for terrorism client's } \\
\text { guidance. The only available work } \\
\text { procedure is for the general } \\
\text { cllient's guidance. }\end{array}$ & Average \\
\hline & $\begin{array}{l}\text { 1.2. The guidance } \\
\text { activity for clients is } \\
\text { implemented according }\end{array}$ & $\begin{array}{l}\text { The guidance activity is } \\
\text { implemented according to the } \\
\text { work procedure available. }\end{array}$ & Good \\
\hline
\end{tabular}




\begin{tabular}{|c|c|c|c|}
\hline & $\begin{array}{l}\text { to the general work } \\
\text { procedure. }\end{array}$ & & \\
\hline $\begin{array}{l}\text { Aspects } \\
\text { Evaluated }\end{array}$ & Evaluation Criteria & Research Findings & Score \\
\hline \multirow{4}{*}{ 3. Cooperation } & $\begin{array}{l}\text { 3.1. There is good } \\
\text { teamwork between } \\
\text { divisions in the } \\
\text { Surakarta correctional } \\
\text { facility. }\end{array}$ & $\begin{array}{l}\text { There is good teamwork between } \\
\text { each division and members in the } \\
\text { Surakarta correctional facilty. }\end{array}$ & Good \\
\hline & $\begin{array}{l}\text { 3.2. Maintaining a good } \\
\text { working relationship } \\
\text { between Surakarta } \\
\text { correctional facility and } \\
\text { the stakeholders. }\end{array}$ & $\begin{array}{l}\text { The relationship with stakeholders } \\
\text { is still not maintained well. As an } \\
\text { example there is no synergy } \\
\text { between the police and the } \\
\text { attorney regarding supervision. }\end{array}$ & Average \\
\hline & $\begin{array}{l}\text { 3.3. Establishing good } \\
\text { cooperation with the } \\
\text { public society. }\end{array}$ & $\begin{array}{l}\text { Cooperation with the public } \\
\text { society has not proceeded well yet. } \\
\text { The public society is still reluctant } \\
\text { in accepting terrorism convicts. }\end{array}$ & Average \\
\hline & $\begin{array}{l}\text { 3.4. Establishing good } \\
\text { cooperation with the } \\
\text { client's family. }\end{array}$ & $\begin{array}{l}\text { Cooperation with the client's } \\
\text { family went well. }\end{array}$ & Good \\
\hline $\begin{array}{l}\text { Aspects } \\
\text { Evaluated }\end{array}$ & Evaluation Criteria & Research Findings & Score \\
\hline \multirow{3}{*}{ 4. Leadership } & $\begin{array}{l}\text { 4.1. Councelors are } \\
\text { involved in decision } \\
\text { making. }\end{array}$ & $\begin{array}{l}\text { Correctional facility officers are } \\
\text { involved in decision making. }\end{array}$ & Good \\
\hline & $\begin{array}{l}\text { 4.2. Reward and } \\
\text { punishment system for } \\
\text { the staffs is maintained } \\
\text { consistently. }\end{array}$ & $\begin{array}{l}\text { Reward and punishment is } \\
\text { consistently maintained and } \\
\text { proporsionally given. }\end{array}$ & Good \\
\hline & $\begin{array}{l}\text { 4.3. Communication } \\
\text { between leader and } \\
\text { subordinates is } \\
\text { maintained well. }\end{array}$ & $\begin{array}{l}\text { Communication between leader } \\
\text { and subordinates is done through } \\
\text { formal and non formal forums. }\end{array}$ & Good \\
\hline $\begin{array}{l}\text { Aspects } \\
\text { Evaluated }\end{array}$ & Evaluation Criteria & Research Findings & Score \\
\hline \multirow{3}{*}{$\begin{array}{l}\text { 5. Control and } \\
\text { Evaluation }\end{array}$} & $\begin{array}{l}\text { 5.1. Client's attendance in } \\
\text { activities is maintained } \\
\text { well. }\end{array}$ & $\begin{array}{l}\text { Most of the clients are present in } \\
\text { guidance program. Proven through } \\
\text { signature attendance checklist. }\end{array}$ & Good \\
\hline & $\begin{array}{l}\text { 5.2. A constant } \\
\text { supervision for the } \\
\text { clients outside the } \\
\text { regular routine schedule. }\end{array}$ & $\begin{array}{l}\text { Supervision outside the routine } \\
\text { schedule is not implemented yet. }\end{array}$ & Poor \\
\hline & $\begin{array}{l}\text { 5.3. Evaluation for the } \\
\text { activities periodically. }\end{array}$ & $\begin{array}{l}\text { The evaluation for the guidance } \\
\text { activities is done annualy. }\end{array}$ & Good \\
\hline
\end{tabular}

Based on the table above, it can be explained that the results of the evaluation of the process component is good. This means that several to lots of evidence meet to the criteria of evaluation. Some aspects of element evaluated are good. Only two element of cooperation and control and evaluation which are external cooperation and supervision outside routine schedule are average and poor. 
The following table shows the results of the evaluation of the implementation of personality guidance and independence at Surakarta Correctional Facility.

\section{Product Component Evaluation}

Whether clients are independent or not is influenced by how the correctional facility is fostering them. Because the Correctional Facility is where clients seek new skills during their mentoring period. The results of the research in the field indicate that almost all clients do not experience additional knowledge from the correctional facility. This was revealed in an interview with a client of terrorism (SF, Interview 27 November 2014) that the subject quality and teaching system did not answer the problem, as revealed in the following statement:

I see the material provided is just like that. I see that it doesn't affect me to find work outside. When I was outside, the one who decides whether I could get a job or not was myself, yes, I was alone with the knowledge I had. What they gave, still didn't provide a solution. I think what I feel is the same as the others.

When the teaching and guidance material provided by Correctional Facility was considered the client had not answer the problem and did not provide a solution, the client's autonomy did not increase anyway. This can be found from the answers of almost all clients who feel that the material provided is not beneficial for the development of future autonomy or independency. It is bad, while the client has spent a long time in guidance but not given appropriate guidance material.

For more details, the following are the results of terrorism client's guidance program evaluation from each individual aspects.

a. Personality aspect. The result for the personality aspect evaluation is good. Out of seven aspect rated, only one aspect received a poor score which is the aspect of accepting the rules and regulations of Indonesia's governmental system based on Pancasila and UUD 45. Half of the guidance target desires an Islamic governmental system based on Islamic law.

b. Autonomy aspect. The result for the autonomy aspect is poor. All the criterias needed are either poor or avarage in score. This is due to the lack of focused analysis for the needs of terrorism client, especially in the economic factor after they are released.

Tabel 5. Product Component Evalation Report

\begin{tabular}{|l|l|l|l|}
\hline $\begin{array}{l}\text { Aspects } \\
\text { Evaluated }\end{array}$ & Evaluation Criteria & Research Findings & Score \\
\hline & $\begin{array}{l}\text { 1.1. Follows the } \\
\text { regulation and rules in } \\
\text { the Surakarta } \\
\text { correctional facilty. }\end{array}$ & $\begin{array}{l}\text { 10 clients are obedient to the rules } \\
\text { and regulations of Surakarta } \\
\text { correctional facility. }\end{array}$ & Good \\
\cline { 2 - 4 } & $\begin{array}{l}\text { 1.2. Can socialize with } \\
\text { the public community. }\end{array}$ & $\begin{array}{l}11 \text { clients are capable of socializing } \\
\text { with the public community by } \\
\text { working in carpentry, opening a } \\
\text { computer business, establisihing } \\
\text { food stalls, etc. }\end{array}$ & Good \\
\cline { 2 - 4 } & $\begin{array}{l}\text { 1.3. Regiously follows } \\
\text { the teachings of their } \\
\text { religions. }\end{array}$ & $\begin{array}{l}\text { Every clients religiously follow in } \\
\text { the teachings of Islam. }\end{array}$ & Excellent \\
\hline
\end{tabular}




\begin{tabular}{|c|c|c|c|}
\hline \multirow{4}{*}{ 1. Personality } & $\begin{array}{l}\text { 1.4. Not associated with } \\
\text { any activities involving } \\
\text { terorism again. }\end{array}$ & $\begin{array}{l}14 \text { clients are not indicated on } \\
\text { returning to their previous circle. }\end{array}$ & Good \\
\hline & $\begin{array}{l}\text { 1.5. Clients acknowledge } \\
\text { and accepts the } \\
\text { governmental system in } \\
\text { Indonesia. }\end{array}$ & $\begin{array}{l}9 \text { clients acknowledges and accepts } \\
\text { the governmental system in } \\
\text { Indonesia. }\end{array}$ & Average \\
\hline & $\begin{array}{l}\text { 1.6. Client does not } \\
\text { judge and are not hostile } \\
\text { to other people with } \\
\text { different } \\
\text { believes/religion from } \\
\text { them. }\end{array}$ & $\begin{array}{l}12 \text { clients does not judge and are not } \\
\text { hostile to other people with different } \\
\text { believes/religion from them. }\end{array}$ & Good \\
\hline & $\begin{array}{l}\text { 1.7. Client does not } \\
\text { support in } \\
\text { terrorism/violent acts. }\end{array}$ & $\begin{array}{l}10 \text { clients does not support in } \\
\text { terrorism/violent acts. While the } \\
\text { other } 8(45 \%) \text { supports in } \\
\text { terorrism/violent acts. }\end{array}$ & Good \\
\hline $\begin{array}{l}\text { Aspects } \\
\text { Evaluated }\end{array}$ & Evaluation Criteria & Research Findings & Score \\
\hline \multirow{3}{*}{ 2. Autonomy } & $\begin{array}{l}\text { 2.1. Clients are confident } \\
\text { and feel optimistic in } \\
\text { leading their future lives. }\end{array}$ & $\begin{array}{l}5 \text { clients are optimistic and confident } \\
\text { in leding their lives alongside the } \\
\text { public society. }\end{array}$ & Poor \\
\hline & $\begin{array}{l}2.2 \text {. Easy to get a job to } \\
\text { provide for their family } \\
\text { and themselves. }\end{array}$ & $\begin{array}{l}\text { Only } 3 \text { clients feels unburdened in } \\
\text { getting a job and providing for their } \\
\text { family and themselves. }\end{array}$ & Poor \\
\hline & $\begin{array}{l}\text { 2.3. Gains knowledge and } \\
\text { skills for work. }\end{array}$ & $\begin{array}{l}\text { Only } 2 \text { clients acknowledge that they } \\
\text { have gained knowledge and skills } \\
\text { through guidance from the } \\
\text { correctional facility. }\end{array}$ & Poor \\
\hline \multirow[t]{2}{*}{ 3. Impact } & $\begin{array}{l}\text { 3.1. Accepted in the } \\
\text { society. }\end{array}$ & $\begin{array}{l}\text { Most of the clients can socialize } \\
\text { with the community around them. }\end{array}$ & Good \\
\hline & $\begin{array}{l}\text { 3.2. Negative stigma } \\
\text { gradually decreases }\end{array}$ & $\begin{array}{l}\text { Public society around the client is } \\
\text { not worried or in fear. }\end{array}$ & Good \\
\hline
\end{tabular}

\section{CONCLUSION}

The result for context evaluation is on the level two which means as average. For more details, the following are the results of terrorism client's guidance program evaluation from each individual aspects, 1) Vision and mission aspect is average, 2) Aspect of the program's goal is average, and 3) Program objective aspect is average. Then the result for the input component evaluation is on level 2 which translates as average. For more details, the following are the results of terrorism client's guidance program evaluation from each individual aspects: 1) Program strategy aspect is average, 2) Program plan aspect is average, 3) Organization preparedness is good, 4) Human resourcess preparedness is good, 5) Facility preparedness aspect is poor, 6) Budget preparedness aspect is poor, 7) Guidance subject preparation aspect is average.

Beside that, the result of the process evaluation is on a good level. For more details, the following are the results of terrorism client's guidance program evaluation from each individual aspects: 1) Mechanism in implementation of behavioural and autonomy activity aspect is good, 2) Work mechanism aspect is good, 3) Cooperation aspect is good, 4) Leadership is good, 5) Control 
and evaluation aspect is average. The result for the component evaluation process is average. For more details, the following are the results of terrorism client's guidance program evaluation from each individual aspects: 1) Personality aspect is good, 2) Autonomy aspect is is poor, and 3) Impact is good. According to the result and discussion on the evaluation of terrorism client guidance program in Surakarta Correctional Fcility, the decision is that the program can continue with a few revision and also increasing the preparation for the implementation of the program.

\section{Recommendation}

1. Formulation for the vision, mission, objective and target of the terrorism guidance program has to be based on the analysis of the needs of terrorism clients. Mainly to moderate their radical ideology and help them to be independent after they are released.

2. Formulate a strategic plan based on establishment of the objective to moderate the client's radical ideology and help them be independent economically.

3. Increase the readiness of human resources available, especially their competence in guiding terrorism clients, through education and training in terrorism countermeasure and radicalism prevention.

4. Increase the readiness of resources for guidance program such as consultation room, skill training hall, transportation and communication resources for the counselor and the terrorism clients.

5. Increase the budget for guidance program by convincing the parent organization that an adequate budget support is needed for this program.

6. Increase the cooperation with stakeholders, especially public figures and related institute, to help prepare the terrorism clients in going back to the public society.

7. Continuous closed supervision outside of the regular counceling schedule to gain a good knowledge on the client's activities.

8. Continuous guidance program evaluation so that a revision can be made as soon as possible if the objectives has strayed from what has been determined before.

Generally speaking, the author recommend the preposition of terrorism client guidance program as illustrated in the following picture.

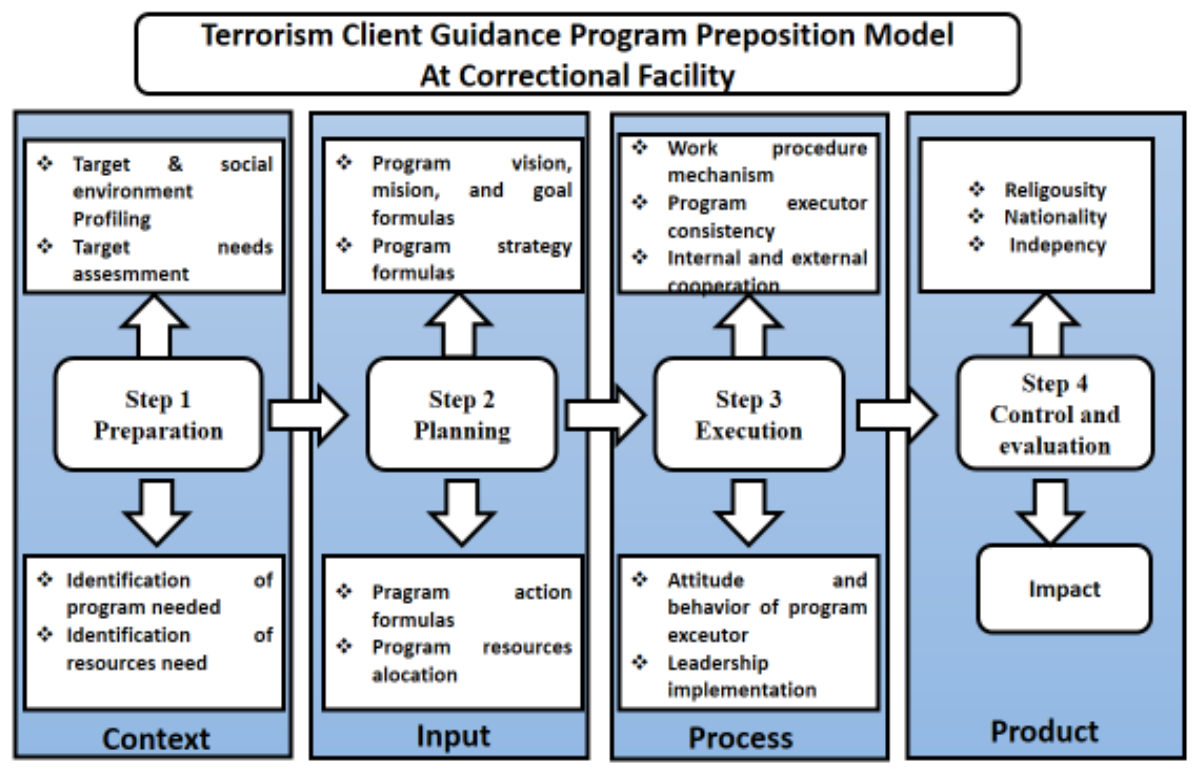

Picture 3. Program Preposition Model Source: Author 


\section{REFERENCES}

Amanda. K, J. (2009). Assesing The Effectiveness of Deradicalization Program on Islamist Extrimist. Security, September.

Arikunto, S., \& Jabar, S. A. (2014). Evaluasi Program Pendidikan: Pedoman Praktis Bagi Mahasiswa dan Praktisi Pendidikan. PT. Bumi Aksara.

Ashour, O. (2009). Deradicalization Islamist Militants. Sage Publication.

Aziz, S., Mahmood, M., \& Rehman, Z. (2018). Implementation of CIPP Model for Quality Evaluation at School Level: A Case Study. Journal of Education and Educational Development, 5(1), 189. https://doi.org/10.22555/joeed.v5i1.1553

Bartol, K. M., \& Martin, D. C. (1991). Manageme, 2nd Edition. McGraw-Hill.

Boucek, C. (2008). Saudi Arabia's "Soft" Counterterrorism Strategy: Prevention, Rehabilitation, and Aftercare. Carnegie Endowment for International Peace, Sep 2008, 27 Pp., 97.

Djaali, \& Mulyono. (2004). Pengukuran dalam Bidang Pendidikan. PPs UNJ.

Ghony, M. D., \& Fauzan Almanshur. (2012). Metode Penelitian Kualitatif. Ar-Ruzz Media.

Golose, P. R. (2009). Deradikalisasi Terorisme: Humanis, Soul Approach, dan Menyentuh Akar Rumput. Yayasan Pengembangan Kajian Ilmu Kepolisian.

Hamka, H. et. al. (2013). Blueprint Deradikalisasi. Badan Nasional Penanggulangan Terorisme.

Istiqomah, M. (n.d.). Deradicalization Program in Indonesian Prisons.

John, H., \& Braddock, K. (2010). Rehabilitating the terrorists?: Challenges in assessing the effectiveness of de-radicalization programs. Terrorism and Political Violence, 22(2), 267 291. https://doi.org/10.1080/09546551003594748

Johnson, A. S. (n.d.). Assesing The Effectiveness of Deradicalization Program on Islamist Extrimist.

Jones, A. J. (1934). Principle of Guidance (2nd Editio). McGraw-Hill.

Kotter, J. P., \& Schlesinger, L. A. (2008). Strategies. August.

Marsh, J. C. (1978). The goal-oriented approach to evaluation: Critique and case study from drug abuse treatment. Evaluation and Program Planning, 1(1), 41-49. https://doi.org/10.1016/0149-7189(78)90006-X

Mintardja, R. (n.d.). Pembinan Narapidana Tindak Pidana Terorisme di Indonesia.

Purwanto, \& Atwi. (1999). Evaluasi Program Diklat. STIA LAN.

Rabasa, A., Pettyjohn, S. L., Ghez, J. J., \& Boucek, C. (2011). Deradicalizing Islamist Extrimist.

Rabassa, A. et. al. (2011). Deradicalizing Islamist Extrimists. Rand Corporation.

Schmid, A. P. (2013). Radicalisation, De-Radicalisation, Counter-Radicalisation: A Conceptual Discussion and Literature Review. ICCT Research Paper.

Stufflebeaml, D., \& Shrinkfield. (1987). The CIPP Model for Program Evaluatioan: Evalation Model, Viewpoint on Educatioal Human Services Evaluaton (Madaus \& Scriven (eds.)). Kluwer-Nijhoff Publshing.

Suratman, Y. P. (2018). The Effectiveness of De-Radicalization Program in Southeast Asia: Does It Work? The Case of Indonesia, Malaysia, and Singapore. JAS (Journal of ASEAN Studies), 5(2), 135. https://doi.org/10.21512/jas.v5i2.4302

Tampubolon, M. P. (2012). Perilaku Keorganisasian: Persfektif Organisasi Bisnis. Ghalia Indonesia.

W.Kruglanski, A., Gelfand, M. J., Belanger, J. J., Sheveland, A., Hetiarachchi, M., \& Gunaratna, R. (2014). The Psychology of Radicalization and Deradicalization: How Significance Que...: EBSCOhost. Advances in Psychology, 35.

Wirawan. (2011). Evaluasi, Teori, Model, Standar, Aplikasi dan Profesi. Raja Grafindo Persada. 